\title{
Ring-enhancing lesions in the brain and spinal cord
}

\author{
Justin Garner, ${ }_{1}^{1}$ Robin Howard ${ }^{2}$
}

${ }^{1}$ Department of Respiratory Medicine, Watford General Hospital, Herts, UK

${ }^{2}$ Department of Neurology, St Thomas' Hospital, London, UK

\section{Correspondence to}

Dr Justin Garner, justin.garner@nhs.net

\section{DESCRIPTION}

A 31-year-old Afro-Caribbean man, previously well, volunteered a 3-week history of drenching night sweats, unsteadiness, weak numb legs, constipation and difficulty passing urine. Examination elicited increased tone in the right leg, distal weakness of left leg, bilateral weak hip flexion, absent reflexes, muted plantar responses, sensory level at T11. Cranial nerve, upper limb and back examinations were normal: no meningism.

Haemoglobin $11.2(13.0-17.0 \mathrm{~g} / \mathrm{dL})$, mean corpuscular volume $89(80-100 \mathrm{fL})$, white cell count 7.7 $\left(4.0-11.0 \times 10^{9}\right)$, C reactive protein $17(0-4 \mathrm{mg} / \mathrm{L})$, erythrocyte sedimentation rate $58(0-15 \mathrm{~mm} / \mathrm{h})$, urea $5.1(1.7-8.3 \mathrm{mmol} / \mathrm{L})$, thyroid stimulating hormone $1.39(0.27-4.20 \mathrm{mIU} / \mathrm{L})$.

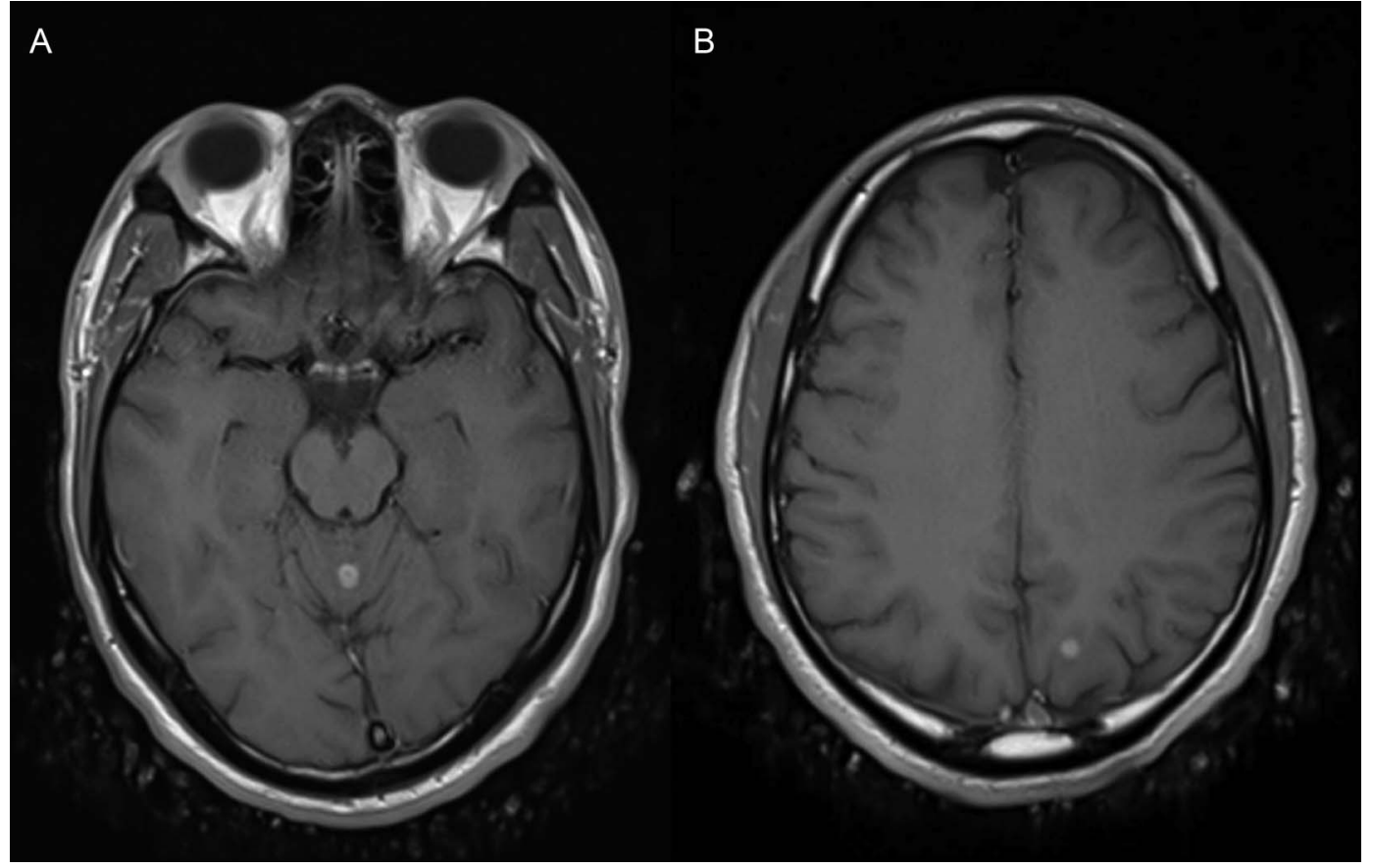

Figure 1 Gadolinium-enhanced T1-weighted axial MRI brain imaging showing ring-enhancing lesions in the superior vermis $(A)$ and the left posterior parietal lobe (B).

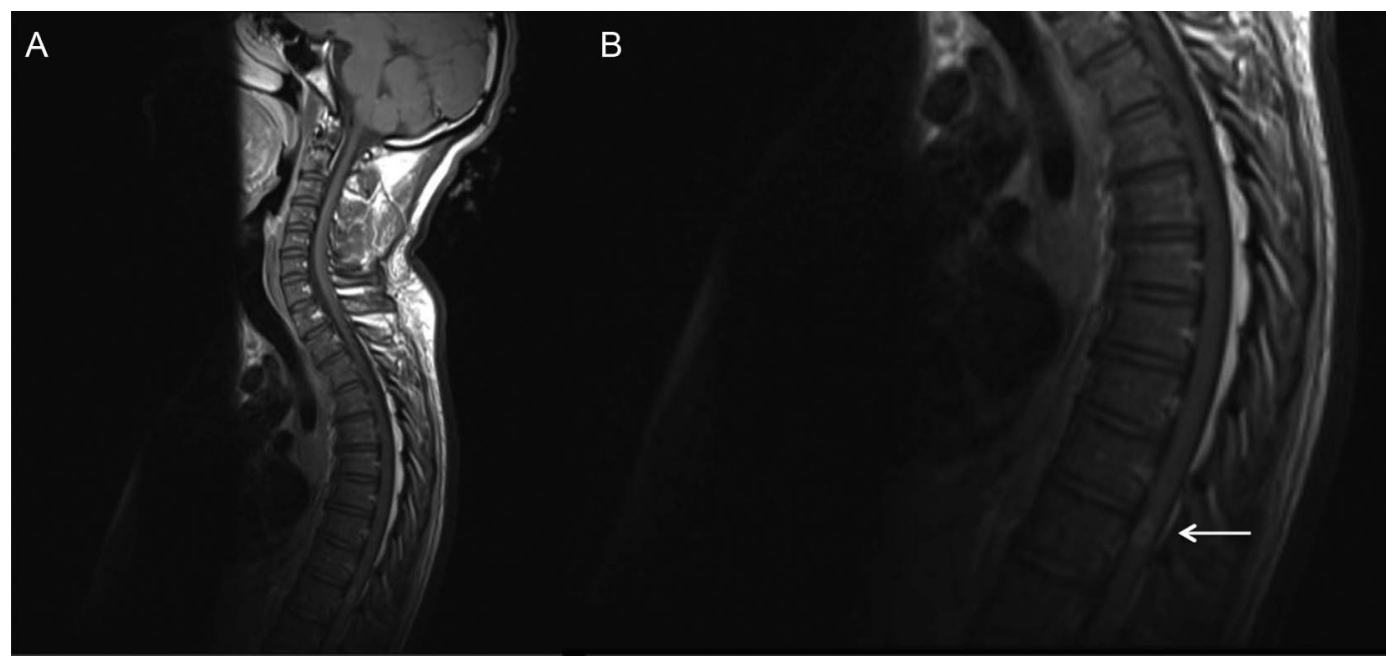

Figure 2 Gadolinium-enhanced T1-weighted sagittal MRI spine imaging showing an intramedullary ring-enhancing lesion at T10 (A) and magnified image (B) with arrow highlighting abnormality. 
MRI revealed ring-enhancing foci in the superior vermis and the left posterior parietal lobe of the brain (figure 1), hyperintensity of the cord mid-thoracic level to conus and an intramedullary ring-enhancing lesion at T10 (figure 2), isointense on T2-weighted imaging. ${ }^{1-3}$ X-ray chest was normal. CT chest, abdomen and pelvis demonstrated subcarinal and paratracheal lymphadenopathy and mid-oesophageal thickening. Positron emission tomography-CT indicated tracer uptake in mediastinal nodes and oesophagus.

Autoimmune and infectious serological screens, HIV and transthoracic echocardiogram were unremarkable. Lumbar puncture was normal. Endoscopic oesophageal biopsies: non-specific inflammation. Endobronchial ultrasound-guided fine needle aspiration of enlarged mediastinal lymph nodes revealed necrotising granulomatous lymphadenitis and acid-fast bacilli on Ziehl-Neelsen staining. Mycobacterium tuberculosis was cultured. The Health Protection Agency identified an infectious cluster suggesting this was likely primary infection. Family screening was negative. He is responding to quadruple therapy and steroids but progress is slow owing to medication side effects.

More common causes of transverse myelitis, viral infection, autoimmune (eg, lupus) and demyelination (eg, multiple sclerosis) are usually treated with steroids. Undiagnosed tuberculosis is likely to be calamitous.
Contributors JG developed the concept of the case report and prepared the draft. $\mathrm{RH}$ was involved in critical revision of the manuscript.

Competing interests None.

Patient consent Obtained.

Provenance and peer review Not commissioned; externally peer reviewed.

\section{REFERENCES}

1 Parmar $\mathrm{H}$, Shah J, Patkar D, et al. Intramedullary tuberculomas. MR findings in seven patients. Acta Radiol 2000;41:572-7.

2 Bernaerts A, Vanhoenacker FM, Parizel PM, et al. Tuberculosis of the central nervous system: overview of neuroradiological findings. Eur Radiol 2003;13:1876-90.

3 Bano S, Chaudhary V, Yadav S. Central nervous system tuberculosis. Neuroimagingclinical applications. In: Bright P, ed. InTech. 2012. http://www.intechopen.com/ books/neuroimaging-clinical-applications/central-nervous-system-tuberculosis

\section{Learning points}

- MRI is the non-invasive modality of choice to characterise cerebrospinal lesions.

- An intramedullary lesion with ring enhancement on T1-weighted imaging, isointense on T2-weighted imaging, is consistent with a tuberculoma, but is not diagnostic.

- Tuberculosis of the spinal cord is both very rare and difficult to diagnose. Cerebrospinal fluid may be normal. Other sites in the body should be sought to recover the organism. Failing this, spinal cord biopsy may be necessary.

Copyright 2013 BMJ Publishing Group. All rights reserved. For permission to reuse any of this content visit http://group.bmj.com/group/rights-licensing/permissions.

BMJ Case Report Fellows may re-use this article for personal use and teaching without any further permission.

Become a Fellow of BMJ Case Reports today and you can:

- Submit as many cases as you like

- Enjoy fast sympathetic peer review and rapid publication of accepted articles

- Access all the published articles

- Re-use any of the published material for personal use and teaching without further permission

For information on Institutional Fellowships contact consortiasales@bmjgroup.com

Visit casereports.bmj.com for more articles like this and to become a Fellow 